\title{
Effects of surface coating on the flexural strength of fluoride- releasing restorative materials after water aging for one year
}

\section{Purpose}

To evaluate the effects of surface coating and one-year water storage on the flexural strength of fluoride-releasing restorative materials.

\section{Materials and Methods}

Forty specimens were prepared from each material; GCP Glass Fill (GCP), Amalgomer CR (AHL), Zirconomer (Shofu), Fuji IX GP Capsule (GC), Beautifil II (Shofu), Estelite $\Sigma$ Quick (Tokuyama) and reliaFIL LC (AHL). The specimens were randomly divided into two groups; surface coated with G-Coat Plus (GC) and uncoated. Each group was subdivided into two groups stored in distilled water at $37^{\circ} \mathrm{C}$ for $24 \mathrm{~h}$ and 1 year before testing $(n=10)$. The flexural strength was evaluated using three-point bending test according to the ISO 4049:2009 standard using a universal testing machine. After flexural strength test, a cross-section of the coated specimens was evaluated with scanning electron microscopy (SEM).

\section{Results}

A significant increase was observed on the flexural strength of Amalgomer $C R$ Zirconomer and Fuji IX GP after $24 \mathrm{~h}$ when G-Coat Plus was applied $(\mathrm{p}<0.05)$. This significant increase was observed on the flexural strength of only Amalgomer CR and Zirconomer after 1 year $(p<0.05)$. The highest flexural strength was obtained with Beautifil II, Estelite $\Sigma$ Quick and reliaFIL LC after $24 \mathrm{~h}$ and 1 year $(p<0.05)$. After 1 year, there was decrease on the flexural strength of the other materials except Beautifil II, Estelite $\Sigma$ Quick and reliaFIL LC.

\section{Conclusion}

The resin coating improved the flexural strength of some glass ionomer-based materials but the water aging decreased the same physical properties.

Keywords: Flexural strength, Glass ionomer cement, Scanning electron microscopy, Surface coating, Water aging

\section{Introduction}

The glass-ionomer cements (GICs) have been widely used in dentistry due to their beneficial properties, such as biological compatibility, chemical adhesion to tooth structure, and especially fluoride release which contribute to caries preventive character $(1,2)$. However, some characteristics of the GICs can limit their indications for clinical use (3). The long setting reaction time and the water sensitivity during setting reactions may cause low mechanical properties of the GICs $(4,5)$. During the setting process, water has an important role for proper maturation of GICs (5). The initial stage, which is the clinical setting reaction, occurs within the first 10 minute after mixing. The second stage, involving the release of the calcium and aluminum ions within the matrix, is a slower continuation of the acid-base reaction that lasts $24 \mathrm{~h} \mathrm{(4).} \mathrm{The} \mathrm{material} \mathrm{is} \mathrm{very} \mathrm{sensitive} \mathrm{to}$ water uptake at the first reaction, while the material is very susceptible to dehydration during the second step. Both water contamination and

\author{
Muhittin Uğurlu' ${ }^{1}$
}

ORCID IDs of the authors: M.U. 0000-0002-8900-7449

'Süleyman Demirel University, Faculty of Dentistry, Department of Restorative Dentistry, Isparta Corresponding Author: Muhittin Uğurlu E-mail: dtmuhittinugurlu@gmail.com Received: 03 May, 2019 Revised: 09 August, 2019 Accepted: 25 October, 2019 DOI: $10.26650 /$ eor.20200042 
dehydration result in incomplete or inadequate maturation of GICs and thus to inferior mechanical properties (4).

When selecting a material to restore teeth, one of the main considerations is mechanical properties of the material (6). The mechanical properties of a direct restorative material need to be strong enough to withstand the forces associated with mastication and other possible loading (7). The materials must also maintain mechanical properties for a long term $(8,9)$. The GICs have been introduced in dental practice by Wilson and Kent in the early 1970s (1). Since then, several researches have been done to enhance their mechanical properties and to expand their clinical applications. Consequently, fluoride-releasing and glass ionomer-based materials have been recently developed. Some of these materials are the high viscosity GIC, the ceramic reinforced GIC, the zirconia reinforced GIC and the GIC containing calcium fluorapatite nanocrystals (10). One of the recent developments in the fluoride-releasing restorative materials has been introduction of the giomer materials. The giomer is a hybridization material of GIC and composite resin, containing surface pre-reacted glass ionomer (S-PRG) filler particles within a resin matrix (3).

In previous studies, the resin coating has been recommended for increasing the clinical performance of glass-ionomer restoration (11) and the mechanical properties of GICs by preventing the water contamination and dehydration (12-16). The coating agent acts as barriers to water so the hardening and maturation processes of GIC can take place unaffected by water uptake and water loss $(13,16)$. It has been reported that the self-adhesive resin coating agent provided a seal of the GIC's surface through high hydrophilicity and low viscosity (17). It has been additionally stated that the coating agent could improve the mechanical properties by filling the surface micro porosities of the materials (14). Reviewing the literature, there is little data on the mechanical properties of the recently developed fluoride-releasing materials and, no information is available regarding the effect of resin coating and water aging on the mechanical properties of these materials $(3,10,12-16)$.

Therefore, the objective of this study was to evaluate the effect of resin coating and one-year water aging on the flexural strength of the fluoride-releasing materials. The null hypothesis tested was the resin coating and water aging would not affect the flexural strength of the materials.

\section{Materials and Methods}

\section{Restoratives}

Five different fluoride-releasing restorative materials were tested in the present study. The restorative materials were a glass carbomer (GCP Glass Fill; GCP, Vianen, Netherlands), a ceramic reinforced GIC (Amalgomer CR; Advanced Healthcare Ltd, Tonbridge, UK), a zirconia reinforced GIC (Zirconomer; Shofu, Kyoto, Japan), a high viscosity GIC (Fuji IX GP Capsule; GC, Tokyo, Japan) and a giomer (Beautifil II; Shofu, Kyoto, Japan). As control, a nano-filled composite resin (Estelite $\Sigma$ Quick; Tokuyama, Tokyo, Japan) and a nano-hybrid composite resin (reliaFIL LC; Advanced Healthcare Ltd, Tonbridge, UK,) were used. The materials are listed in Table 1 with the composition, manufacturer and lot number. A nano-filled surface sealant agent (G-Coat Plus; GC, Tokyo, Japan, Lot:1710031) was also tested.

\section{Specimen preparation}

The $25 \times 2 \times 2 \mathrm{~mm}$ bar-shaped forty specimens were prepared from each material. After the materials were inserted into the teflon mould, the polyester strips (Mylar strip; SS White Co., Philadelphia, PA, USA) were pressed onto the mould surfaces with glass plates to extrude excess material and obtain a flat surface. The giomer and composite resins were polymerized through the glass plate using a LED light-curing unit (Smartlite Focus; Dentsply, Milford, DE, USA) according to the manufacturer's instructions (Table 2). The intensity of the curing light (Smartlite Focus; Dentsply, Milford, DE, USA) was measured before and after application and the light output was never below $1000 \mathrm{~mW} / \mathrm{cm}^{2}$. For GCP Glass Fill and Fuji IX GP, a capsule mixer (Silver Mix; Stomamed, Bratislava, Slovakia) was used for 10 seconds of mixing before application of the material. Amalgomer CR and Zirconomer were mixed within a total of 30 seconds according to the manufacturer's instructions (Table 2). After the light curing and setting cycle, the specimens were removed from the mould. In order to obtain flat surface, both side of the specimens were gently polished manually with a circular motion with 1000-grit and 1500-grit wet silicon carbide papers. Each specimen was brief rinsed in tap water between each grit. After the polishing procedure, the specimens were randomly divided into two groups according to coated with G-Coat Plus and uncoated. G-Coat Plus was applied using a micro-tip applicator, then gently air thinned for 5 seconds and light cured for 20 seconds with the LED light curing unit (Smartlite Focus; Dentsply, Milford, DE, USA, $1000 \mathrm{~mW} / \mathrm{cm}^{2}$ ) according to manufacturer's instructions. Only one surface of the specimens was coated as in a clinical application. All the specimens were prepared at room temperature $\left(21 \pm 1^{\circ} \mathrm{C}\right)$ in $55 \%$ relative humidity. The temperature and humidity were measured with a digital thermometer. Each group was subdivided into the two groups stored in distilled water at $37^{\circ} \mathrm{C}$ for $24 \mathrm{~h}$ and 1 year before testing. The ten specimens were tested in each subgroup $(n=10)$.

\section{Flexural strength}

The flexural strength was evaluated using three-point bending test according to the ISO 4049:2009 standard with a $20-\mathrm{mm}$ span at a crosshead speed of $1 \mathrm{~mm} / \mathrm{min}$ on a universal testing machine (Autograph AGS-X; Shimadzu, Kyoto, Japan). Before testing, the specimen dimensions were measured using a digital caliper (Digimatic Caliper, Mitutoyo, Tokyo, Japan). The flexural strength (FS) of the material was calculated by $\mathrm{FS}=3 \mathrm{P}_{\max } \mathrm{L} /\left(2 \mathrm{bh}^{2}\right)$, where $\mathrm{P}_{\max }$ is the maximum load $(N)$ on the load-displacement curve, $L$ is the span length $(\mathrm{mm}), \mathrm{b}$ is the width of the specimen $(\mathrm{mm})$ and $\mathrm{h}$ is the thickness of the specimen $(\mathrm{mm})$.

\section{SEM analysis}

After flexural strength test, a cross-section of a specimen was randomly selected in each coated group for SEM analysis. All specimens were adhered with conductive carbon tape to aluminum stubs and observed under SEM (Quanta Feg 250, FEl, Netherlands) with secondary electrons at $\times 500$, $\times 1000$ and $\times 2000$ magnification by $20 \mathrm{kV}$. 
Table 1. The composition of the materials according to the manufacturers' data

\begin{tabular}{|c|c|c|c|c|}
\hline Materials & Type & Composition & Manufacturer & Lot \\
\hline GCP Glass Fill & Glass carbomer & $\begin{array}{l}\text { Fluoroaluminosilicate glass, nano fluoro/ } \\
\text { hydroxyapatite, polyacids }\end{array}$ & $\begin{array}{l}\text { GCP, Vianen, } \\
\text { Netherlands }\end{array}$ & 71702144 \\
\hline Amalgomer CR & $\begin{array}{l}\text { Ceramic } \\
\text { reinforced GIC }\end{array}$ & $\begin{array}{c}\text { Powder: Fluoroaluminosilicate glass, polyacrylic } \\
\text { acid powder, tartaric acid powder, ceramic } \\
\text { reinforcing powder. } \\
\text { Liquid: Polyacrylic acid, distilled water }\end{array}$ & $\begin{array}{l}\text { Advanced Healthcare } \\
\text { Ltd, Tonbridge, UK }\end{array}$ & 011804-81 \\
\hline Zirconomer & $\begin{array}{l}\text { Zirconia reinforced } \\
\text { GIC }\end{array}$ & $\begin{array}{l}\text { Powder: Fluoroaluminosilicate glass, zirconium } \\
\text { oxide, pigments } \\
\text { Liquid: Polyacrylic acid solution, tartaric acid }\end{array}$ & Shofu, Kyoto, Japan & 02160281 \\
\hline Fujı IX GP & $\begin{array}{l}\text { High viscosity } \\
\text { GIC }\end{array}$ & $\begin{array}{l}\text { Polyacrylic acid, fluoroaluminosilicate glass, } \\
\text { polybasic carboxylic acid }\end{array}$ & GC, Tokyo, Japan & $180110 \mathrm{~A}$ \\
\hline Beautifil II & Giomer & $\begin{array}{l}\text { BISGMA, TEGDMA, inorganic glass filler, aluminium } \\
\text { oxide, silica, prereacted glass ionomer filler, } \\
\text { Camphoroquinone }\end{array}$ & Shofu, Kyoto, Japan & 111787 \\
\hline Estelite $\Sigma$ Quick & $\begin{array}{l}\text { Nano-filled } \\
\text { composite resin }\end{array}$ & $\begin{array}{l}\text { Bis-GMA, TEGDMA, silica zirconia fillers, silica-titania } \\
\text { fillers, photoinitiators }\end{array}$ & Tokuyama, Tokyo, Japan & E699 \\
\hline reliaFIL LC & $\begin{array}{l}\text { Nano-hybrid } \\
\text { composite resin }\end{array}$ & $\begin{array}{l}\text { Bis-GMA,TEGDMA, fluoroboroaluminosilicate glass } \\
\text { fillers, photoinitiators }\end{array}$ & $\begin{array}{l}\text { Advanced Healthcare } \\
\text { Ltd, Tonbridge, UK }\end{array}$ & $021722-8$ \\
\hline
\end{tabular}

Bis-GMA: Bisphenol A diglycidyl methacrylate; TEGDMA: Triethylene glycole dimethacrylate

Table 2. The application procedures of the materials according to manufacturer instructions

\begin{tabular}{|c|c|}
\hline Materials & Application procedure \\
\hline GCP Glass Fill & $\begin{array}{l}\text { Before activation shake the capsule or tap its side on a hard surface to loosen the powder. } \\
\text { For activation push the plunger on a plane surface to the end of the capsule. } \\
\text { Insert the capsule into a universal capsule gun and click once to standardize. } \\
\text { Insert the capsule into a mixer and mix the capsule for } 10-15 \text { seconds with high frequency mixers. } \\
\text { Remove the pin from the nozzle after mixing. } \\
\text { Insert the capsule into the capsule gun and pull the lever } 2 \text { times ( } 2 \text { clicks) to prime. } \\
\text { Within } 15 \text { seconds maximum after mixing, start to extrude the mixture directly into the preparation. }\end{array}$ \\
\hline Amalgomer CR & $\begin{array}{l}\text { Powder to liquid ratio } 3.6 \mathrm{~g} / 1.0 \mathrm{~g}(3.6: 1.0 \mathrm{~m} / \mathrm{m}) \\
\text { Use a glass block for best results and a stainless steel "Silicate" spatula. } \\
\text { Incorporate half the powder into the liquid as quickly as possible (5-10 seconds) and then add the remainder and } \\
\text { spatulate to a thick putty-like consistency. } \\
\text { Total mixing time } 30 \text { seconds. } \\
\text { Do not add powder in small increments. }\end{array}$ \\
\hline Zirconomer & $\begin{array}{l}\text { Powder to liquid ratio } 3.6 \mathrm{~g} / 1.0 \mathrm{~g}(3.6: 1.0 \mathrm{~m} / \mathrm{m}) \\
\text { Dispense two level scoops of powder with the measuring scoop provided onto a mixing pad. } \\
\text { Then, dispense one drop of liquid separately. } \\
\text { Divide the dispensed powder into } 2 \text { equal portions; introduce the first half to the dispensed liquid and mix for } 5-10 \\
\text { second with the plastic spatula } \\
\text { Then, add the remaining half and mix until it reaches a thick putty-like consistency. } \\
\text { Mixing must be completed within a total of } 30 \text { second. }\end{array}$ \\
\hline Fujı IX GP & $\begin{array}{l}\text { Before activation, shake the capsule or tap its side on a hard surface to loosen the powder. } \\
\text { To activate the capsule, push the plunger until it is flush with the main body and hold it down for } 2 \text { seconds. } \\
\text { Immediately set it into a mixer (or an amalgamator) and mix for } 10 \text { seconds }(\sim 4,000 \text { RPM) } \\
\text { Immediately remove the mixed capsule from the mixer and load it into the GC Capsule Applier. } \\
\text { Make two clicks to prime the capsule then syringe. } \\
\text { The working time is } 2 \text { minutes from start of mixing. } \\
\text { Within } 10 \text { seconds maximum after mixing, start to extrude the mixture directly into the preparation. }\end{array}$ \\
\hline Beautifil II & $\begin{array}{l}\text { Dispense the necessary amount of material from the syringe. } \\
\text { Light cure for } 20 \text { seconds (halogen lamp) or } 10 \text { seconds (high power LED light). }\end{array}$ \\
\hline Estelite $\Sigma$ Quick & $\begin{array}{l}\text { Dispense the necessary amount of material from the syringe. } \\
\text { Light cure for } 20 \text { seconds (halogen lamp) or } 10 \text { seconds (high power LED light). }\end{array}$ \\
\hline reliaFIL LC & $\begin{array}{l}\text { Dispense the necessary amount of material from the syringe. } \\
\text { Light cure for } 30 \text { seconds (halogen lamp) or } 10 \text { seconds (high power LED light). }\end{array}$ \\
\hline
\end{tabular}




\section{Statistical analysis}

Statistical analyses were performed with the SPSS Program, version 20.0 (Statistical Package for the Social Sciences; SPSS, Chicago, IL, USA). The Kolmogorov-Smirnov test was applied to verify if the data were normally distributed. The mean flexural strength values of the material groups were compared using one-way ANOVA and Duncan posthoc tests. An independent t test analyzed the differences in flexural strength values of the materials, evaluating the effect of coating and aging. The $p$-value less than 0.05 was considered statistically significant for all statistical analyses.

\section{Results}

The flexural strength values were shown in Table 3 and graphically presented in Figure 1. The higher flexural strength values were obtained with Beautifil II, Estelite $\Sigma$ Quick and reliaFIL LC than other materials after $24 \mathrm{~h}$ and 1 year regardless of coating $(p<0.05)$. A significant increase was observed on the flexural strength of Amalgomer CR, Zirconomer and Fuji IX GP after $24 \mathrm{~h}$ when G-Coat Plus was applied $(\mathrm{p}<0.05)$. After 1 year, the coating significantly increased the flexural strength of Amalgomer CR and Zirconomer $(p<0.05)$. The water aging significantly decreased the flexural strength of

Table 3. The mean flexural strength values (MPa) and standard deviations of the materials ( $n=10$ for each subgroups)

\begin{tabular}{|c|c|c|c|}
\hline & \multicolumn{3}{|c|}{ Flexural Strength } \\
\hline & 24 hours & 1 year & $\mathbf{p}^{\ddagger}$ \\
\hline GCP Glass Fill & $31.27 \pm 4.18^{a}$ & $25.60 \pm 3.94^{\mathrm{a}}$ & 0.002 \\
\hline GCP Glass Fill Coated & $30.54 \pm 4.06^{\mathrm{a}}$ & $26.46 \pm 3.91^{\mathrm{a}}$ & 0.013 \\
\hline $\mathbf{p}^{+}$ & 0.698 & 0.630 & \\
\hline Amalgomer CR & $35.74 \pm 5.29^{\mathrm{ab}}$ & $31.86 \pm 4.65^{\mathrm{ab}}$ & 0.161 \\
\hline Amalgomer CR Coated & $45.06 \pm 4.41^{c d}$ & $41.95 \pm 5.09^{c}$ & 0.008 \\
\hline $\mathbf{p}^{+}$ & 0.000 & 0.000 & \\
\hline Zirconomer & $35.58 \pm 3.94^{\mathrm{ab}}$ & $33.96 \pm 3.81^{\mathrm{b}}$ & 0.008 \\
\hline Zirconomer Coated & $44.12 \pm 4.81^{c}$ & $41.90 \pm 5.33^{c}$ & 0.321 \\
\hline $\mathbf{p}^{+}$ & 0.000 & 0.001 & \\
\hline Fujı IX GP & $41.29 \pm 4.95^{\mathrm{bc}}$ & $45.27 \pm 4.46^{c}$ & 0.122 \\
\hline Fujı IX GP Coated & $51.82 \pm 5.48^{d}$ & $48.27 \pm 3.46^{c}$ & 0.014 \\
\hline $\mathbf{p}^{+}$ & 0.000 & 0.110 & \\
\hline Beautifil II & $114.75 \pm 10.64^{\mathrm{e}}$ & $111.34 \pm 10.16^{d}$ & 0.232 \\
\hline Beautifil II Coated & $115.51 \pm 12.08^{\mathrm{e}}$ & $114.17 \pm 11.38^{\text {de }}$ & 0.729 \\
\hline $\mathbf{p}^{+}$ & 0.884 & 0.564 & \\
\hline Estelite $\Sigma$ Quick & $121.04 \pm 11.34 \mathrm{e}$ & $119.10 \pm 10.00^{\mathrm{e}}$ & 0.185 \\
\hline Estelite $\Sigma$ Quick Coated & $122.58 \pm 11.44^{e}$ & $120.23 \pm 10.64^{e}$ & 0.437 \\
\hline $\mathbf{p}^{+}$ & 0.766 & 0.810 & \\
\hline reliaFIL LC & $117.95 \pm 11.17^{e}$ & $116.62 \pm 11.42^{\mathrm{de}}$ & 0.673 \\
\hline reliaFIL LC Coated & $117.40 \pm 11.68^{\mathrm{e}}$ & $114.94 \pm 11.03^{\text {de }}$ & 0.362 \\
\hline $\mathbf{p}^{+}$ & 0.916 & 0.742 & \\
\hline
\end{tabular}

Same small superscript letter indicates no statistical difference in the column; $\mathbf{p}^{\dagger}$ : Significance levels of the uncoated and coated groups of each material; $\mathbf{p}^{\ddagger}$ : Significance levels of the 24 hours and 1 -year groups.

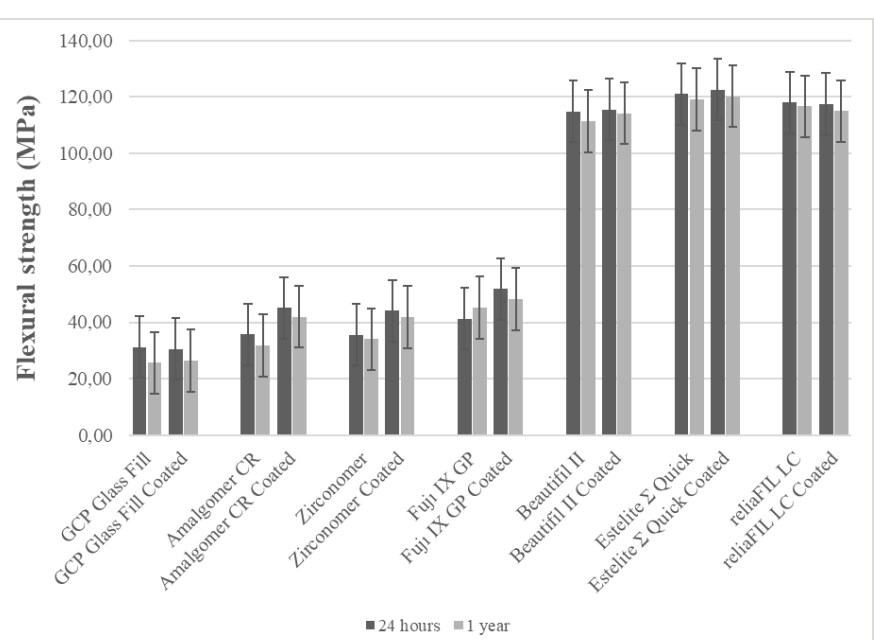

Figure 1. The mean flexural strength values of the materials after 24 hours and 1 year.

GCP Glass Fill, GCP Glass Fill Coated, Amalgomer CR Coated, Zirconomer, Fuji IX GP Coated groups $(p<0.05)$.

The SEM micrographs were presented in Figure 2. The SEM micrographs showed that there was a micro-mechanical interlocking between the materials and the coating agent after $24 \mathrm{~h}$ and 1 year.

\section{Discussion}

This study evaluated the flexural strength of the fluoride-releasing restorative materials and the composite resins which were commonly used as restorative materials. The effects of surface coating and one-year water aging on the flexural strength of the materials were investigated in the present study. The flexural strength test is commonly used to evaluate and compare the mechanical properties of dental materials in laboratory conditions (18-20). The flexural strength has been defined as the maximum stress that a material subjected to a bending load can resist before failure (20). It is regarded as the most important measure of strength for dental materials because considerable flexural stresses occur during the complex mastication process $(18,20)$. The restorative materials must have high flexural strength to enhance the longevity of the restorations. $(13,18)$. The minimum requirement of flexural strength for occlusal restorations is $80 \mathrm{MPa}$ according to ISO 4049 (18). In the present study, GCP Glass Fill, Amalgomer CR, Zirconomer and Fuji IX GP did not meet the minimum requirement of ISO 4049 for occlusal restorations. The resin coating and water aging influenced the flexural strength of some fluoride-releasing materials. Therefore, the null hypothesis, that the resin coating and water aging would not affect the flexural strength of the materials, was partially rejected.

The setting process of GICs generally is characterized by interaction between a polyacid liquid and a glass powder in form of acid-base reaction. This reaction continues by a stepwise rather long-lasting setting (21). The changes in mechanical properties of GICs occur within the first $24 \mathrm{~h}$ and, the changes can be observed over several weeks or months (5). The coating is recommended during the initial setting stage of conventional GICs for a proper maturation $(5,12)$. The setting process of GCP Glass Fill, Amalgomer CR, Zirconomer and Fuji IX GP occur in form of acid-base reac- 


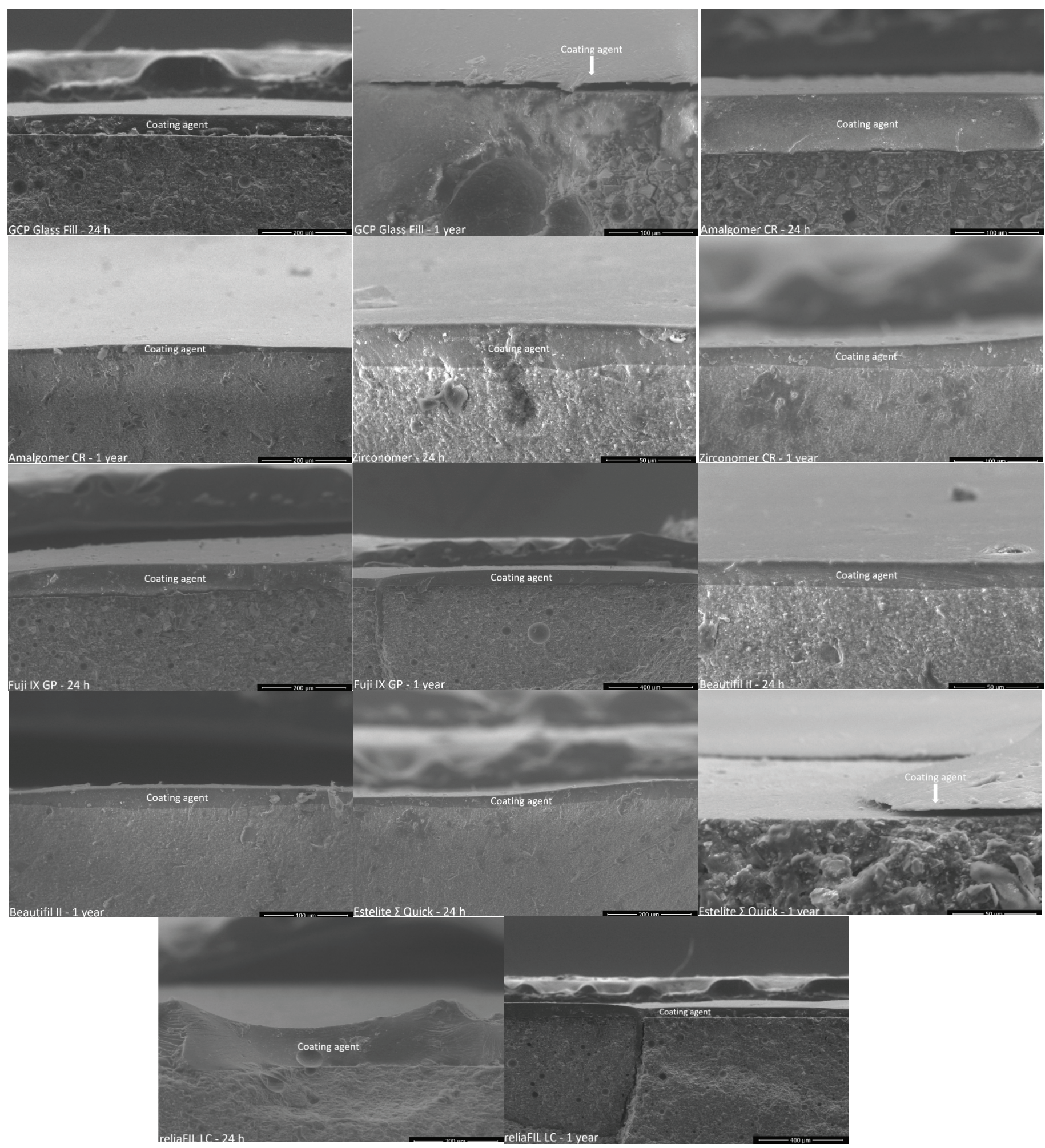

Figure 2. SEM photomicrograph of the cross-section of the coated specimens after $24 \mathrm{~h}$ and 1 year. The SEM micrographs of all the materials showed that there was a micro-mechanical interlocking between the materials and the coating agent after $24 \mathrm{~h}$ and 1 year.

tion like a conventional GIC. In the present study, the surface coating significantly increased the flexural strength of Amalgomer CR, Zirconomer and Fuji IX GP after 24 h. As reported in previous studies, the increase could be due to that the coating agent exerted control on the setting process of the materials within $24 \mathrm{~h}$ (12-16).

The protective effect of the coating from extrinsic water may allow complete maturation of the GIC reaction with delayed water exposure, thus possibly creating a stronger material while it may not reinforce the surface of the material (16).
Previous studies concluded that significant improvement of wear resistance (13), shear punch strength (16), and flexural strength (13-15) of Fuji IX GP after coating with G Coat Plus before water contamination. It has been also reported that the strength increases in coated GIC resulted from that the protective coating contributes to the GIC strength by improving the maturation process and not by the inherent strength of the coating layer (12). In this study, the surface coating did not affect the flexural strength of GCP Glass Fill after $24 \mathrm{~h}$. It could result from different moisture sensitivity of GCP Glass 
Fill. According to the manufacturer, heat application is recommended for GCP Glass Fill during the setting reaction to increase its mechanical properties. But it has been concluded that the gloss and heat application with LED curing unit did not influence the flexural strength of GCP Glass Fill (22). This result has been attributed to different chemical composition and moisture sensitivity of the material (22). After 1 year, the coating increased the flexural strength of Amalgomer CR and Zirconomer. As reported in a previous study, it could be due to that the coating agent reduced the surface porosity and crack propagation on the GICs (16).

In this study, the glass ionomer-based materials GCP Glass Fill, Amalgomer CR, Zirconomer and Fuji IX GP showed lower flexural strength than Beautifil II and the composite resins regardless of coating and water aging. It has been previously reported that the giomer and composite resins had higher mechanical properties than GICs (14,23-25). In the present study, the coating did not influence the flexural strength of Beautifil II and the composite resins regardless of water storage. This result can be due to the high flexural strength of the materials. It has been stated that during the three-point bending test, the crack starts from within the specimen not from the surface, therefore the coating does not play a role on materials which are more resistant to flexural stresses (13).

The water aging is one of the most widely used procedures in experimental studies to evaluate the performance of materials and simulate the physiological aging of materials (8). It has been stated that the storage agent had a low effect on the mechanical properties, furthermore the storage time was more important factor $(4,15)$. The water aging can cause detrimental effect on GICs, as it erodes the surface of the material and induces hydrolysis and dissolution of GICs' components $(26,27)$. The water uptake in conventional GIC is rapid due to the hydrogel structure and large micropores on the surface, therefore a substantial decrease in strength and elasticity of the material may occur (28). The water aging can also cause plasticization of the resin component in the composite resins due to water sorption. Therefore, the longterm storage in water can influence mechanical properties of the composite resins (29). Furthermore, it has been also reported that the effects of water aging could be related to the composition of composite resins and GICs $(7,29)$.

A previous study has concluded that the flexural strength of Fuji IX GP showed an increase up to 3 months and then, decreased after 6 months water aging (14). The improvement in the strength up to 3 months has been attributed to the acid-base reaction that proceeds slowly until final maturation completion which may take a few months (30). It has been stated that the storage time was an effective factor in the flexural strength of either uncoated and coated GICs (14). In the present study, the 1-year water aging did not affect the flexural strength of Beautifil II and the composite resins regardless of coating; however, it decreased the flexural strength values on GCP Glass Fill, Amalgomer CR, Zirconomer and Fuji IX GP. As stated in a previous study, the decrease could attribute to water uptake of the materials (7). The decrease of flexural strength was not observed on Zirconomer coated group. It could be due to that the coating can reduce water uptake. It has been reported that the coating with $\mathrm{G}$ Coat Plus could be beneficial for reducing water absorption of GIC (31). But, in this study, the coating did not show the same effect for each glass ionomer-based material. The differences could result from different chemical composition and water uptake of the materials. Unfortunately, in this study, the water uptake was not evaluated.

In the present study, the SEM micrographs showed that there was still a micro-mechanical interlocking between the materials and the coating agent after 1 year, but it was stated that the masticatory forces could cause debonding the coating agent over time in oral environment (12). The in vitro researches cannot exactly reflect the actual status of the oral cavity since oral environment is dynamic and different from laboratory conditions. But the laboratory studies simulating most clinical conditions are very useful to assess behavior of biomaterials $(14,16)$. The longevity is one of the most important considerations of restorations (32). Therefore, the restorative materials are evaluated with in vitro studies to determine if they are susceptible to degradation during longterm using. Besides the in vitro studies, further clinical studies are also needed to investigate the performance of the fluoride-releasing materials and the effects of resin coating.

\section{Conclusion}

Within the limitations of this study, the resin coating provided a valuable support for some of the glass ionomer-based materials, since it led to significant improvements in flexural strength of the materials. The giomer and composite resins had higher mechanical properties than the glass ionomer-based materials regardless of coating and water aging. The one-year water aging decreased the flexural strength of the glass ionomer-based materials while it did not affect the flexural strength of the giomer and composite resins.

Türkçe Özet: Yüzey örtülemenin bir yıl suda yaşlandırmadan sonra florid salan restoratif materyallerin eğilme dayanımına etkisi. Amaç: Yüzey örtüleme ve bir yıl suda yaşlandırmanın florid salan restoratif materyallerin eğilme dayanımı üzerindeki etkilerini değerlendirmek. Gereç ve Yöntem: Her materyalden kırk örnek hazırlandı; GCP Glass Fill (GCP), Amalgomer CR (AHL), Zirconomer (Shofu), Fuji IX GP Kapsül (GC), Beautifil II (Shofu), Estelite $\Sigma$ Quick (Tokuyama) ve reliaFIL LC (AHL). Örnekler, G-Coat Plus (GC) ile yüzey örtülenmiş ve örtülenmemiş olarak rastgele iki gruba ayrıldı. Her grup testten önce $37^{\circ} \mathrm{C}$ 'de distile su içinde 24 saat ve 1 yıl saklanan iki alt gruba ayrıldı $(n=10)$. Eğilme dayanımı, universal test cihazında ISO 4049:2009 standardına göre üç nokta eğilme testi kullanılarak değerlendirildi. Eğilme dayanımı testinden sonra, yüzeyi örtülenmiş örneklerin bir kesiti taramalı elektron mikroskobu ile değerlendirildi. Bulgular: Amalgomer CR, Zirconomer ve Fuji IX GP'nin 24 saat sonundaki eğilme dayanımında, G-Coat Plus uygulandığında önemli bir artış gözlendi ( $p<0.05)$. Bu artış, 1 yıl sonunda sadece Amalgomer $C R$ ve Zirconomer 'in eğilme dayanımında gözlenmiştir $(p<0.05)$. En yüksek eğilme dayanımı değerleri 24 saat ve 1 yıl sonunda Beautifil II, Estelite $\Sigma$ Quick ve reliaFIL LC ile elde edildi ( $p<0.05)$. Beautifil II, Estelite $\Sigma$ Quick ve reliaFIL $L C$ hariç diğer materyallerin eğilme dayanımı 1 yıl sonunda azalmıştır ( $p>0.05$ ). Sonuç: Rezin örtüleme, bazı cam iyonomer bazlı materyallerin eğilme dayanımında artışlar sağlamıştır. Suda yaşlandırma, cam iyonomer bazlı materyallerin eğilme dayanımını azaltmıştır. Anahtar kelimeler: Cam iyonomer siman, Eğilme dayanımı, Suda yaşlandırma, Taramalı elektron mikroskobu, Yüzey örtüleme

Acknowledgements: The author thanks to Shofu Dental, GC Corporation, Dual Dental and Advanced Healthcare Ltd, for the material support of this study, and Salih AKYUREKLI for SEM analyses.

Ethics Committee Approval: Not required. 
Informed Consent: Not required.

Peer-review: Externally peer-reviewed.

Author contributions: MU designed the study, generated and gathered the data, wrote and approved the final version of the study.

Conflict of Interest: The author had no conflict of interest to declare.

Financial Disclosure: The author declared that he received no financial support.

\section{References}

1. Wilson $A D$, Kent BE. A new translucent cement for dentistry. The glass ionomer cement. Br Dent J 1972;132:133-5. [CrossRef]

2. Wiegand A, Buchalla W, Attin T. Review on fluoride-releasing restorative materials--fluoride release and uptake characteristics, antibacterial activity and influence on caries formation. Dent Mater 2007;23:343-62. [CrossRef]

3. Garoushi S, Vallittu PK, Lassila L. Characterization of fluoride releasing restorative dental materials. Dent Mater J 2018;37:293300. [CrossRef]

4. Nicholson JW. Maturation processes in glass-ionomer dental cements. Acta Biomater Odontol Scand 2018;4:63-71. [CrossRef]

5. Ilie N. Maturation of restorative glass ionomers with simplified application procedure. J Dent 2018;798:46-52. [CrossRef]

6. Xie D, Brantley WA, Culbertson BM, Wang G. Mechanical properties and microstructures of glass-ionomer cements. Dent Mater 2000;16:129-38. [CrossRef]

7. Bagheri R, Azar MR, Burrow MF, Tyas MJ. The effect of aging on the fracture toughness of aesthetic restorative materials. Am J Dent 2010;23:142-6.

8. Zhou X, Wang S, Peng X, Hu Y, Ren B, Li M, et al. Effects of water and microbial-based aging on the performance of three dental restorative materials. J Mech Behav Biomed Mater 2018;80:4250. [CrossRef]

9. Feng J, Cheng L, Zhou X, Xu HHK, Weir MD, Li Q, et al. Effects of water aging on the mechanical and anti-biofilm properties of glass-ionomer cement containing dimethylaminododecyl methacrylate. Dent Mater 2019;35:434-443. [CrossRef]

10. Ching HS, Luddin N, Kannan TP, Ab Rahman I, Abdul Ghani NRN. Modification of glass ionomer cements on their physicalmechanical and antimicrobial properties. J Esthet Restor Dent 2018;30:557-571. [CrossRef]

11. Diem VT, Tyas MJ, Ngo HC, Phuong LH, Khanh ND. The effect of a nano-filled resin coating on the 3-year clinical performance of a conventional high-viscosity glass-ionomer cement. Clin Oral Investig 2014;18:753-9. [CrossRef]

12. Lohbauer U, Krämer N, Siedschlag G, Schubert EW, Lauerer B, Müller FA, et al. Strength and wear resistance of a dental glassionomer cement with a novel nanofilled resin coating. Am J Dent 2011;24:124-8.

13. Bonifácio CC, Werner A, Kleverlaan CJ. Coating glass-ionomer cements with a nanofilled resin. Acta Odontol Scand 2012;70:471-7. [CrossRef]

14. Bagheri R, Palamara J, Mese A, Manton DJ. Effect of a selfadhesive coating on the load-bearing capacity of tooth-coloured restorative materials. Aust Dent J 2017;62:71-78. [CrossRef]

15. Zoergiebel J, Ilie N. Evaluation of a conventional glass ionomer cement with new zinc formulation: effect of coating, aging and storage agents. Clin Oral Investig 2013;17:619-26. [CrossRef]
16. Bagheri R, Taha NA, Azar MR, Burrow MF. Effect of G-Coat Plus on the mechanical properties of glass-ionomer cements. Aust Dent J 2013;58:448-53. [CrossRef]

17. Pacifici E, Bossù M, Giovannetti $A$, La Torre G, Guerra F, Polimeni A. Surface roughness of glass ionomer cements indicated for uncooperative patients according to surface protection treatment. Ann Stomatol (Roma) 2014;4:250-8.

18. Pameijer CH, Garcia-Godoy F, Morrow BR, Jefferies SR. Flexural strength and flexural fatigue properties of resin-modified glass ionomers. J Clin Dent 2015;26:23-7.

19. Faridi MA, Khabeer A, Haroon S. Flexural Strength of Glass Carbomer Cement and Conventional Glass lonomer Cement Stored in Different Storage Media over Time. Med Princ Pract 2018;27:372-377. [CrossRef]

20. Wang L, D’Alpino PH, Lopes LG, Pereira JC. Mechanical properties of dental restorative materials: relative contribution of laboratory tests. J Appl Oral Sci 2003;11:162-7. [CrossRef]

21. Algera TJ, Kleverlaan CJ, Prahl-Andersen B, Feilzer AJ. The influence of environmental conditions on the material properties of setting glass-ionomer cements. Dent Mater 2006;22:852-6. [CrossRef]

22. Menne-Happ U, Ilie N. Effect of gloss and heat on the mechanical behaviour of a glass carbomer cement. J Dent 2013;41:223-30. [CrossRef]

23. Chen S, Öhman C, Jefferies SR, Gray H, Xia W, Engqvist H. Compressive fatigue limit of four types of dental restorative materials. J Mech Behav Biomed Mater 2016;61:283-289. [CrossRef]

24. Gajewski VE, Pfeifer CS, Fróes-Salgado NR, Boaro LC, Braga RR. Monomers used in resin composites: degree of conversion, mechanical properties and water sorption/solubility. Braz Dent J 2012;23:508-14. [CrossRef]

25. Walia R, Jasuja P, Verma KG, Juneja S, Mathur A, Ahuja L. A comparative evaluation of microleakage and compressive strength of Ketac Molar, Giomer, Zirconomer, and Ceram-x: An in vitro study. J Indian Soc Pedod Prev Dent 2016;34:280-4. [CrossRef]

26. Bapna MS, Gadia CM, Drummond JL. Effects of aging and cyclic loading on the mechanical properties of glass ionomer cements. Eur J Oral Sci 2002;110:330-4. [CrossRef]

27. Musanje L, Shu M, Darvell BW. Water sorption and mechanical behaviour of cosmetic direct restorative materials in artificial saliva. Dent Mater 2001;17:394-401. [CrossRef]

28. Cefaly DF, Franco EB, Mondelli RF, Francisconi PA, Navarro MF. Diametral tensile strength and water sorption of glass-ionomer cements used in Atraumatic Restorative Treatment. J Appl Oral Sci 2003;11:96-101. [CrossRef]

29. Ricci WA, Alfano P, Pamato S, Cruz CADS, Pereira JR. Mechanical Degradation of Different Classes of Composite Resins Aged in Water, Air, and Oil. Biomed Res Int 2019;2019:7410759. [CrossRef]

30. Roberts HW, Berzins DW, Charlton DG. Hardness of three resinmodified glass-ionomer restorative materials as a function of depth and time. J Esthet Restor Dent 2009;21:262-72. [CrossRef]

31. Hankins AD, Hatch RH, Benson JH, Blen BJ, Tantbirojn D, Versluis A. The effect of a nanofilled resin-based coating on water absorption by teeth restored with glass ionomer. J Am Dent Assoc 2014;145:363-70. [CrossRef]

32. Kim KL, Namgung C, Cho BH. The effect of clinical performance on the survival estimates of direct restorations. Restor Dent Endod 2013;38:11-20. [CrossRef] 